\title{
Burrowing by badgers (Meles meles) and foxes (Vulpes vulpes) changes soil conditions and vegetation in a European temperate forest
}

Received: 21 March 2013/Accepted: 1 November 2013/Published online: 22 November 2013

(C) The Author(s) 2013. This article is published with open access at Springerlink.com

\begin{abstract}
This study examined the effects of burrow digging and habitation by the European badger (Meles meles) and the red fox (Vulpes vulpes) on soil properties and the plant community. The vegetation of control plots located in a similar but undisturbed habitat was compared with that of 18 burrow plots established at badger setts $(N=9)$ and fox dens $(N=9)$ in a lowland forest area in Poland. Soil physicochemical properties at different disturbance levels (mounds, intermounds and reference areas) were also investigated. The animals altered nutrient availability in the burrow plots considerably by excavating material from deep soil horizons that were less acidic and higher in $\mathrm{K}, \mathrm{Ca}, \mathrm{Mg}$ and available $\mathrm{P}$ but poorer in $\mathrm{C}$ and $\mathrm{N}$. The effect was stronger for the badger, probably because it displaced larger amounts of material and disturbed wider areas. The activity of the two carnivores induced similar changes in plant communities. They increased herbaceous species richness and caused a shift in the herbaceous species composition: versus the control plots, the burrow plots contained more fugitive species (short-living plants typical for disturbed environments), among which ruderal forbs, including nutrient-demanding species, dominated. The carnivores also increased the species richness of fleshyfruited shrubs and trees. The primary reason for this was probably not burrowing but endozoochorous seed dispersal. Overall, the results indicate that the badger setts and fox dens differ significantly from the forest matrix in terms of soil and vegetation parameters, and that they
\end{abstract}

P. Kurek $(\bowtie) \cdot$ P. Kapusta $\cdot$ J. Holeksa

Władysław Szafer Institute of Botany, Polish Academy of Sciences, Lubicz 46, 31-512 Kraków, Poland

E-mail: p.kurek@botany.pl

Tel.: + 48-12-4241742

Fax: + 48-12-4219790

P. Kapusta

E-mail: p.kapusta@botany.pl

J. Holeksa

E-mail: j.holeksa@botany.pl contribute to habitat heterogeneity and biological diversity.

Keywords Soil disturbance - Burrowing carnivore Soil physicochemical property · Plant community · Seed dispersal

\section{Introduction}

Natural small-scale disturbances can substantially influence ecosystem structure and functioning. Locally, they cause the release of different resources such as nutrients, light and water (Goszczyńska and Goszczyński 1977; Hobbs and Mooney 1985; Wilson and Tilman 1993; Huntly and Reichman 1994; Canals and Sebastiá 2000; Kerley et al. 2004; Borchard et al. 2008), and reduce interspecific competition, allowing new species to establish (Wilson and Tilman 1993; Kinlaw 1999; Kyle et al. 2007). On the landscape scale they add to habitat patchiness (heterogeneity), and in consequence boost species diversity (Veen and Olff 2011). Soil mixing and displacement by living organisms, called biopedturbation, are examples of such disturbances (Wilkinson et al. 2009). This may result from an animal burrowing for shelter or digging for food. This form of activity is observed in a wide variety of animals from worms to mammals. The latter are perhaps the most well-known; usually they are small herbivores and insectivores inhabiting mainly arid and semi-arid environments (e.g., gophers, rabbits, porcupines, pack rats, marsupials, moles). Many of them have been recognized as ecosystem engineers (sensu Jones et al. 1994), as they occur in great densities and dramatically alter the physical habitat and ecological communities (Eldridge and Myers 2001; Garkaklis et al. 2004; Kerley et al. 2004; Eldridge and Whitford 2009; Whitford and Steinberger 2010).

Some carnivore species also exert biopedturbation effects, but they are rarely studied in the context of disturbance impacts on ecosystems. Their populations 
are generally small, individuals are spread over wide areas due to territoriality, and they spend a relatively short time burrowing. However, there is some evidence that, as burrowers, they may play a key role in increasing habitat patchiness and biological diversity. For instance, the arctic fox Alopex lagopus, through burrowing, creates "islands" of vegetation that are very distinct against the surrounding tundra (Bruun et al. 2005). The islands are sparse on the landscape but, together with other microhabitats (e.g., snow-bed margins), they are important refuges for many plant species that cannot exist in undisturbed places. In the temperate forests of Europe, the European badger Meles meles and the red fox Vulpes vulpes might have a similar effect on environment and vegetation.

The European badger and the red fox are two of the most widespread carnivores on the continent. They may occur sympatrically in many different habitats (Jędrzejewska and Jędrzejewski 1998), sometimes even dwelling in the same burrow system (Kowalczyk et al. 2008). Badgers tend to exploit soil more intensely than foxes do, especially when they live in big social groups. Their burrows (setts) serve for resting, breeding and winter sleep (Neal and Roper 1991). They may have many entrances, tunnels and chambers, which are cleaned regularly, enlarged from year to year, and inherited by succeeding generations (Neal and Roper 1991; Kowalczyk et al. 2004). Such setts may be inhabited for decades or even centuries (Kowalczyk et al. 2004). Badgers produce various soil disturbances such as mounds, well-trodden paths and latrines. The size of a disturbed area ranges from tens to hundreds of square meters (Obidziński et al. 2013). Foxes build similar but generally smaller and simpler constructions called dens. Only for a short time, i.e., during winter and the mating period, do they use them intensively (Uraguchi and Takahashi 1998; Goszczyński and Wójtowicz 2001). Foxes generate disturbances of lower intensity and spatial extent than do badgers. These disturbances are quite numerous in the landscape because foxes live at relatively high densities and change dens many times in their lifetime (Gołdyn et al. 2003).

Badgers and foxes may also influence ecological communities by processes other than burrowing. They are well-known for marking their territories with urine and feces. There is some evidence that a substantial part of the animal manure is deposited in the close vicinity of burrows (Neal and Roper 1991; Hutchings et al. 2001; Kowalczyk et al. 2004) and that this may lead to local eutrophication. Deposition of feces may also be associated with seed dispersal of plants producing fleshy fruit, which during some periods are an important component of the carnivore diet (Goszczyński et al. 2000; Sidorovich et al. 2006; Fedriani and Delibes 2009; Fedriani et al. 2010; Rosalino and Santos-Reis 2009; Rost et al. 2012).

The consequences of burrowing and burrow usage by medium-size carnivores have rarely been studied comprehensively. Most studies have limited their focus to the differences between herbaceous communities developed on burrows and in the surrounding matrix (Van Wijngaarden and van de Peppel 1964; Stubbe 1965; Neal and Roper 1991; Neal and Cheeseman 1996; Bruun et al. 2005). These differences cannot be fully understood without having supplementary data on soil physicochemical properties, which are thought to vary considerably between disturbed and undisturbed places (e.g., Eldridge and Koen 2008). In this study, we compared badger setts and fox dens to undisturbed reference areas in terms of both soil parameters $(\mathrm{pH}$, nutrient content, particle size distribution) and vegetation (plant species richness and composition, individual species abundance). Our aim was to (1) determine the nature of changes in forest communities induced by burrowing, and (2) examine the differences between the two carnivore species in their impact on soil and vegetation.

\section{Methods}

The study was carried out in the Kampinos Forest, one of the biggest (ca. $385 \mathrm{~km}^{2}$ ) and best-preserved lowland forest complexes in central Poland. It is situated in the Vistula River Valley, north and west of Warsaw $\left(52.26^{\circ}-\right.$ $52.40^{\circ} \mathrm{N}, 20.28^{\circ}-20.88^{\circ} \mathrm{E} ; 68-106$ m.a.s.1.). As in other parts of Poland, a transitional climate (with continental and marine influences) prevails here. It is characterized by high variability of weather conditions across months and years. The growing season lasts 185 days, the average annual temperature is $7.7^{\circ} \mathrm{C}$, and average annual precipitation amounts to $546 \mathrm{~mm}$ (Andrzejewski 2003). The dominant substrate is sand of glaciofluvial and fluvial origin. A large part of the sand is windtransformed and forms dunes overgrown mostly with pine and mixed oak-pine forests (Dicrano-Pinion). Between the dunes are wetter habitats such as peat bogs and marshy forests with Alnus glutinosa.

Badger and fox burrows were surveyed over the central and eastern part of the forest area, mostly during the 2009-2010 spring seasons. The burrows were identified as being either badger setts or fox dens by tracks, evidence of burrow-cleaning methods, paths, and direct observations of animals (Kowalczyk et al. 2000; Panek and Bresiński 2002). The burrows were classified as breeding or non-breeding sites on the basis of additional signs such as fecal droppings, tracks of cubs, trodden ground and food leftovers (Panek and Bresiński 2002). Only breeding sites were considered in this study. We selected the 18 best-developed burrows (nine badger, nine fox) that were in use as breeding sites and situated in similar habitat types (pine or mixed oak-pine forest). These burrows were distributed irregularly in the study area and separated from each other by a distance of $0.4-7 \mathrm{~km}$.

Two circular plots covering $100 \mathrm{~m}^{2}$ were established at each site. One of them covered a forest fragment disturbed by burrowing activity (burrow plot), and the other, established $50 \mathrm{~m}$ away in a random direction, represented the same type of habitat but without visible 
signs of animal disturbance (control plot). Each plot $(N=36)$ was described in terms of stand age (based on increment cores taken from three trees with the largest trunk diameter), tree species richness, basal area (BA) of dominating tree species (Scots pine Pinus sylvestris in all cases), and BA of admixture species. For each plot, the abundance of plant species in the field layer was estimated on the Braun-Blanquet scale (coded 1-6, where 1, $<1 \%$ cover; 2, 1-5\% cover; 3, 6-25\% cover; 4, $26-50 \%$ cover; $5,51-75 \%$ cover; and $6,>75 \%$ cover). Total cover of vascular plants in the field layer, and bryophytes and lichens in the ground layer, was estimated to the nearest $10 \%$. The understory plants of each shrub and tree species producing fleshy fruits were counted. Plant nomenclature follows Mirek et al. (2002).

At each site, soil samples representing three levels of animal disturbance were collected: dome-shaped soil mounds built at burrow entrances $(M)$; the intermound area (I) including the ground trodden by animals and/or partly covered with soil originating from the burrows; and the reference area $(\mathrm{R})$, a fragment of the forest floor not visibly affected by animals. The first two categories (M, I) were sampled within the burrow plots, and the latter (R) within the control plots. After removal of the $\mathrm{O}$ horizon (i.e., the soil organic layer; if present), topsoil samples were taken with a corer $(3.5 \mathrm{~cm}$ diameter) to $10 \mathrm{~cm}$ depth. For each soil sample category (M, I, R), soil was collected at five spots (separated from each other by a distance of at least $1.5 \mathrm{~m}$ ) and bulked to one composite sample.

The composite soil samples $(N=54)$ were sieved through $2 \mathrm{~mm}$ mesh. The particle size distribution (sand, silt and clay fractions) was then determined by a combination of sieving and sedimentation. Soil suspension $\mathrm{pH}$ was measured electrometrically following extraction with $\mathrm{H}_{2} \mathrm{O}(1: 5 \mathrm{w}: \mathrm{v})$. Total $\mathrm{C}$ content was analyzed by dry combustion using a LECO SC-144DRPC analyzer (Leco, http://www.leco.com), and total $\mathrm{N}$ was determined with a method based on Kjeldahl digestion using a Kjeltec 2300 (FossTecator). Na, K, Ca and Mg content was measured by flame atomic absorption spectrometry (Varian $220 \mathrm{FS}$, http://www.home.agilent.com) following hot $\mathrm{HClO}_{4}$ digestion. Phosphorus was determined with a spectrophotometer (Hach-Lange DR 3800, http://www.hach-lange.de): total $\mathrm{P}$ after mineralization with $\mathrm{HClO}_{4}$, and available $\mathrm{P}$ in $0.5 \mathrm{M} \mathrm{NaHCO}$ soil extracts (Olsen method).

Statistical analyses were performed with Statistica 9 (Statsoft, Tulsa, OK) and R v2.13.1 (R Development Core Team 2009). Prior to statistical tests, the data were transformed with logarithmic or exponential functions to obtain a normal or at least symmetric distribution. Split-plot ANOVA (with sites acting as blocks) was used to examine the disturbance level effect $(\mathrm{M}, \mathrm{I}$ and $\mathrm{R}$; within-block factor) and the carnivore species effect (badger vs fox; between-block factor) on soil physicochemical properties. By the same method we estimated the disturbance effect (burrow vs control; within-block factor) and the carnivore species effect on vegetation parameters (species richness and cover of field layer, species richness and individual density of fleshy-fruited shrubs and trees). Split-plot ANOVA was also computed to compare forest stand parameters between badger and fox sites and between burrow and control plots. Indicator species analysis (Dufrêne and Legendre 1997) was performed using the "indval" function from the "labdsv" package (Roberts 2012) to reveal species preference for plot type (BB, badger burrow plot; $\mathrm{BC}$, badger control plot; FB, fox burrow plot; FC, fox control plot).

\section{Results}

\section{Tree stand characteristics}

All sites were in habitats with similar conditions: coniferous forests dominated by Scots pine on sandy soils. However, there were some differences in stand preference between carnivore species (Table 1). Badgers setts were found in forests having higher tree species richness and a greater admixture of broadleaved trees (expressed as basal area), mainly Quercus robur, than the forest sites with fox dens (Fig. 1). The fox dens were associated almost exclusively with Scots pine monoculture. The tree stands at the badger sites tended to be older $(71.0 \pm 30.5$ years) than those at the fox sites $(49.5 \pm 25.7$ years), though this difference was not significant. No stand characteristics varied significantly between the burrow and control plots (Table 1; Fig. 1).

\section{Soil physicochemical properties}

Topsoil physicochemical properties were modified considerably by animal-caused disturbance (Table 2; Fig. 2). Burrowing activity had a particularly strong effect on soil $\mathrm{pH}$ : the average $\mathrm{pH}$ of mounds and intermounds was significantly higher than for reference areas. Similarly, the mound and intermound concentrations of metals such as $\mathrm{K}, \mathrm{Ca}$ and $\mathrm{Mg}$ were higher than those recorded from reference areas. Mounds also had the highest content of plant-available P, but they contained significantly less total $\mathrm{C}$ and $\mathrm{N}$ than intermound and reference areas. There were no differences in $\mathrm{Na}$, total $\mathrm{P}$, or soil particle size distributions between disturbance categories.

Badger sites differed from fox sites in most soil physicochemical properties (Table 2; Fig. 2). The former were richer than the latter in all macronutrients except $\mathrm{P}$ (both total and available). Badger site soil also contained significantly more clay and silt in relation to sand than did fox site soil. There were no differences between badger and fox sites in $\mathrm{pH}$ or in total and available $\mathrm{P}$.

Although the effect of the interaction between disturbance level and carnivore species was not statistically significant (Table 2), badger activity tended to affect soil properties more strongly than did fox activity. Versus 
Table 1 Results of split-plot ANOVA on the differences in vegetation parameters between fox and badger sites (the effect of species), and between burrow and control plots (the effect of disturbance). BA Stand basal area, FFST fleshy-fruited shrubs and trees in the understory

\begin{tabular}{|c|c|c|c|c|c|c|}
\hline \multirow[t]{3}{*}{ Variables } & \multirow{2}{*}{\multicolumn{2}{|c|}{$\frac{\text { Between blocks (error } d f=16)}{\text { Species }(d f=1)}$}} & \multicolumn{4}{|c|}{ Within blocks (error $d f=16$ ) } \\
\hline & & & \multicolumn{2}{|c|}{ Disturbance $(d f=1)$} & \multicolumn{2}{|c|}{ Species $\times$ disturbance $(d f=1)$} \\
\hline & $F$ & $P$ & $F$ & $P$ & $F$ & $P$ \\
\hline Stand age & 2.56 & 0.129 & 0.05 & 0.833 & 0.29 & 0.597 \\
\hline Total BA & 0.32 & 0.578 & 0.01 & 0.922 & 0.00 & 0.978 \\
\hline BA of Scots pine & 3.92 & 0.065 & 1.10 & 0.311 & 1.33 & 0.265 \\
\hline BA of admixture species & 43.61 & $<0.001 *$ & 0.39 & 0.540 & 0.73 & 0.407 \\
\hline Tree species richness & 17.72 & $0.001 *$ & 0.14 & 0.716 & 0.11 & 0.740 \\
\hline Field layer coverage & 0.07 & 0.788 & 0.18 & 0.677 & 0.00 & 0.985 \\
\hline Ground layer coverage & 23.08 & $<0.001 *$ & 0.01 & 0.912 & 2.08 & 0.168 \\
\hline Field layer species richness & 1.00 & 0.331 & 22.40 & $<0.001^{*}$ & 0.10 & 0.758 \\
\hline Density of FFST & 4.78 & $0.044 *$ & 0.15 & 0.702 & 7.53 & $0.014 *$ \\
\hline Species richness of FFST & 6.67 & $0.020 *$ & 10.20 & $0.004 *$ & 0.12 & 0.732 \\
\hline
\end{tabular}

$* P<0.05$

the reference area, badger mounds contained almost twice as much $\mathrm{K}, \mathrm{Mg}$ and available $\mathrm{P}$, over three times more $\mathrm{Ca}$, and about half the $\mathrm{N}$ (Fig. 2). For the fox sites these differences were much smaller.

\section{Herbaceous vegetation}

Of the 75 species listed in the survey, as many as 31 were recorded exclusively in burrow plots, 6 were found exclusively in control plots, and the remaining 38 were present in plots of both types. Burrow plots had higher field layer species richness than control plots but did not differ in total plant cover in the field and ground layers (Table 1; Fig. 1). The herbaceous vegetation characteristics did not differ significantly between the badger and fox sites except for ground layer cover, which was higher at fox sites (Table 1; Fig. 1).

Animal disturbance caused a considerable shift in species composition, but this applied only to hemicryptophytes (Fig. 3), whose species richness was significantly higher in burrow plots than in control plots (split-plot ANOVA, $F=38.3, \quad P<0.001)$. Other forms - geophytes, therophytes, herbaceous chamaephytes and woody plants - did not show such variation. Different hemicryptophyte species were associated with badger setts and fox dens (Table 3). Chelidonium majus, Festuca gigantea, Geum urbanum, Mycelis muralis and Urtica dioica were significant indicators for badger burrow plots, whereas Hieracium pilosella and Peucedanum oreoselinum indicated fox burrow plots. The control plot vegetation was typical for pine and mixed oak-pine forests. For the badger (BC) it represented a more fertile community variant (with Rubus plicatus, Pteridium aquilinum, Convallaria majalis, Maianthemum bifolium, Dryopteris carthusiana), and for the fox (FC) a poorer one (with Melampyrum pratense, Calamagrostis epigejos, Trientalis europaea).
Fleshy-fruited shrubs and trees

We recorded 17 species of fleshy-fruited shrubs and trees in the survey, most of them (14) in both burrow and control plots. The carnivore species effect was significant for species richness and for total fleshy-fruited shrub and tree density (Table 1): their average values were higher for badger sites (Fig. 1). The species richness of this plant group was also affected positively by animal disturbance, and their total density by the disturbance $\times$ carnivore interaction (Table 1; Fig. 1). Only two species were significant indicators for burrow plots-Sambucus nigra and Prunus cerasifera. They occurred mainly at badger setts. Frangula alnus, on the other hand, was associated with the control plots of badger sites.

\section{Discussion}

\section{Habitat differences between badger and fox sites}

Our results indicate that badgers and foxes differ significantly in their preference for the habitat conditions in which they dig their burrows. Badgers prefer sites with more fertile soil (i.e., having a higher content of nutrients) supporting higher diversity of trees, shrubs and herbaceous plants. This preference is likely associated with food availability. Soil invertebrates, mainly insects and earthworms, are a major component of the badger diet (Kruuk 1978; Goszczyński et al. 2000; Kowalczyk et al. 2003). These prey are abundant under broadleaved trees due to the favorable conditions of the soil and litter, but sparse under conifers (Kowalczyk et al. 2003). This makes mixed oak-pine forests a better alternative than poor pine monocultures for badgers-badgers establishing setts there will save time on foraging activity and/or be better nourished. The fox 

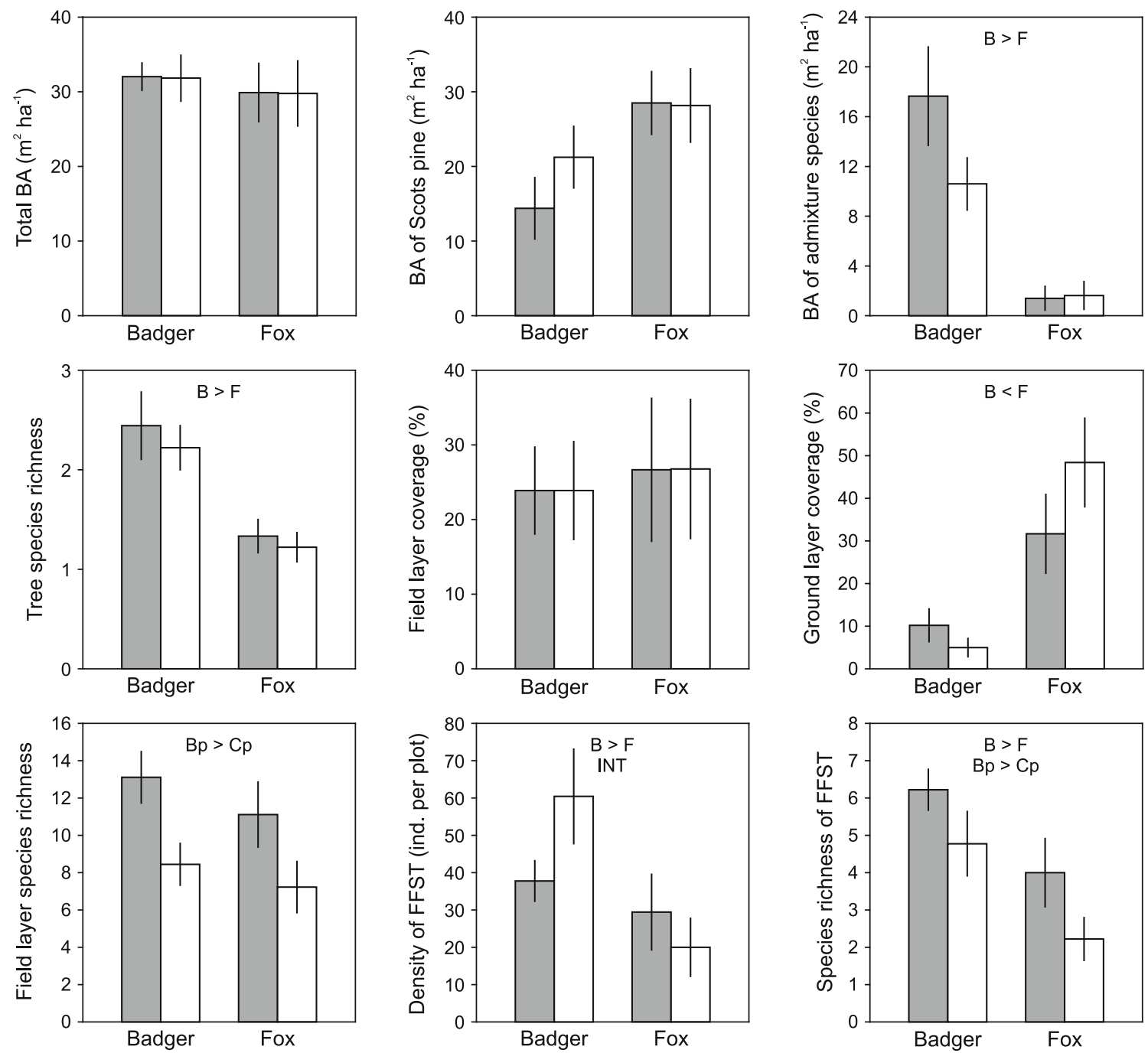

$\square$ Burrow plot (Bp) $\square$ Control plot (Cp)

Fig. 1 Vegetation parameters (means and standard errors) determined for burrow $(\mathrm{Bp})$ and control $(\mathrm{Cp})$ plots at badger (B) and fox (F) sites. Inequality signs indicate significant differences for the disturbance effect (between $\mathrm{Bp}$ and $\mathrm{Cp}$ ) and for the species

diet also includes invertebrates but they feed mainly on voles and other small mammals (Goszczyński 1986; Kidawa and Kowalczyk 2011), so the fertility of the forest surrounding their burrows is not as important for them as the distance to open areas, where voles tend to occur in great numbers (Kidawa and Kowalczyk 2011; Kurek 2011).

Species requirements for soil structural properties are another possible explanation for the habitat differences between badger and fox sites. In comparison to fox dens, badger setts can be large constructions, which are created and inhabited continually for years (Kowalczyk et al. 2004). Durability of such constructions depends greatly on the clay minerals content in the soil. It is possible that badgers' association with richer forest communities reflect these animals' preference for more cohesive ground, site effect (between B and F). INT Significant factor interaction, $B A$ stand basal area, FFST fleshy-fruited shrubs and trees in the understory

i.e., containing more clay and silt (according to the Kampinos Forest Inspectorate unpublished data, two badger sites were situated on cambisols, two on brunic arenosols, and four on podzols). Contrary to badgers, foxes do not need to build solid multifunctional burrows; they utilize dens for a short time, for breeding purposes and as an occasional resting place (Goszczyński and Wójtowicz 2001). Therefore, they do not avoid poor sandy soil (eight fox sites were situated on podzols and one on brunic arenosol).

\section{Animal activity effects on soil properties}

A characteristic feature of temperate forest soils is a distinct increase of $\mathrm{pH}$ with depth (e.g., Blaser et al. 
Table 2 Results of split-plot ANOVA on the differences in soil physicochemical properties between fox and badger sites (the effect of species), and between mound (M), intermound (I) and reference (R) areas (the effect of disturbance)

\begin{tabular}{|c|c|c|c|c|c|c|}
\hline \multirow[t]{3}{*}{ Variables } & \multirow{2}{*}{\multicolumn{2}{|c|}{$\frac{\text { Between blocks (error } d f=16)}{\text { Species }(d f=1)}$}} & \multicolumn{4}{|c|}{ Within blocks (error $d f=32$ ) } \\
\hline & & & \multicolumn{2}{|c|}{ Disturbance $(d f=2)$} & \multicolumn{2}{|c|}{ Species $\times$ disturbance $(d f=2)$} \\
\hline & $F$ & $P$ & $F$ & $P$ & $F$ & $P$ \\
\hline $\mathrm{pH}$ & 1.68 & 0.213 & 26.26 & $<0.001^{*}$ & 2.64 & 0.087 \\
\hline $\mathrm{Na}$ & 8.80 & $0.009^{*}$ & 1.72 & 0.196 & 0.08 & 0.924 \\
\hline $\mathrm{K}$ & 8.63 & $0.010^{*}$ & 4.88 & $0.014 *$ & 1.01 & 0.376 \\
\hline $\mathrm{Ca}$ & 7.64 & $0.014^{*}$ & 4.83 & $0.015^{*}$ & 1.05 & 0.361 \\
\hline $\mathrm{Mg}$ & 7.81 & $0.013^{*}$ & 4.42 & $0.020 *$ & 0.86 & 0.433 \\
\hline $\mathrm{P}$ & 3.57 & 0.077 & 2.13 & 0.135 & 3.19 & 0.054 \\
\hline $\mathrm{P}_{\mathrm{Ols}}$ & 2.56 & 0.129 & 4.27 & $0.023 *$ & 0.90 & 0.416 \\
\hline $\mathrm{C}$ & 8.60 & $0.010^{*}$ & 32.13 & $<0.001 *$ & 0.98 & 0.385 \\
\hline $\mathrm{N}$ & 11.75 & $0.003^{*}$ & 6.11 & $0.006^{*}$ & 0.84 & 0.442 \\
\hline Sand & 6.65 & $0.020^{*}$ & 1.69 & 0.201 & 1.10 & 0.344 \\
\hline Silt & 5.77 & $0.029 *$ & 1.10 & 0.344 & 1.16 & 0.325 \\
\hline Clay & 6.75 & $0.019 *$ & 1.35 & 0.273 & 0.73 & 0.488 \\
\hline
\end{tabular}

$* P<0.05$

2008; Neupane and Roberts 2009). This is the result of topsoil acidification by products of tree litter decomposition and microbial respiration, as well as by plant root exudates (Jobbágy and Jackson 2003; Brady and Weil 2004). In such conditions some alkali and alkalineearth cations leach downward (Jobbágy and Jackson 2001; Brady and Weil 2004), increasing the differences in chemistry between upper and lower soil horizons. Medium-size burrowing carnivores like badgers or foxes can break this stratification. They are able to move considerable amounts of material from deeper layers to the surface, so that the burrow plots, both the mound and the intermound areas, become less acidic and generally better supplied with $\mathrm{K}, \mathrm{Ca}$ and $\mathrm{Mg}$ than the control plots. The latter effect-increased metal content - was evident only for the badger sites, probably because on average badgers excavate more material from deeper horizons than foxes do, and/or because they dig in medium that is inherently more stratified (steeper gradients within the soil profile). Other authors have reported similar observations in studies of different animals: elevated alkali or alkaline-earth metal concentrations and higher $\mathrm{pH}$ in mounds made by rabbits (Eldridge and Myers 2001), pocket gophers (Kerley et al. 2004), moles (Canals and Sebastiá 2000) and American badgers (Eldridge and Whitford 2009).

Higher topsoil $\mathrm{pH}$ in the burrow plots than in the reference plots was accompanied by elevated phosphorus availability. Possibly this results from the relationship between phosphorus transformation and soil $\mathrm{pH}$. The concentration of plant-available $\mathrm{P}$ is highest in slightly acidic ( $\mathrm{pH}$ 5.5-6.0) to neutral ( $\mathrm{pH}$ 7) soils (Havlin et al. 1999). Beyond this range, $\mathrm{P}$ becomes increasingly tied up as aluminum and iron phosphates (acid soils) or as calcium phosphates (alkaline soils). In this study, mounds had $\mathrm{pH}$ values close to the $\mathrm{P}$ availability optimum, and the reference soil was more acid.
Burrowing also strongly affects the total $\mathrm{N}$ and $\mathrm{C}$ distribution in soils. In most soils these elements accumulate in upper horizons in the form of organic matter. Badgers and foxes bury part of the original topsoil under excavated material, which is poor in organic substances, and this reduces nutrient availability around their burrows. The dilution of the $\mathrm{N}$ pool is likely to be compensated somewhat by $\mathrm{N}$ input with urine and feces regularly left by animals as territory marking (Goszczyński 1990; Hutchings et al. 2001; Kowalczyk et al. 2004). Unfortunately, we cannot estimate the magnitude of such fertilization since we did not measure the soil concentration of different forms of $\mathrm{N}$ such as ammonia and nitrate ions.

\section{Animal activity effects on vegetation}

It is well documented that soil-disturbing animals substantially affect plant communities (Van Wijngaarden and van de Peppel 1964; Stubbe 1965; Neal and Roper 1991; Neal and Cheeseman 1996; Bruun et al. 2005; Obidziński and Głogowski 2005; Obidziński and Kiełtyk 2006). Through burrowing or digging for food they add to habitat heterogeneity and reduce interspecific competition, creating opportunities for new plant species to establish successfully and persist (Mayer et al. 2004). A shift in community composition often is accompanied by an increase in community diversity and/or biomass (e.g., Boeken et al. 1995; Questad and Foster 2007; Wesche et al. 2007; Gálvez-Bravo et al. 2011). Our results are in line with those findings: soil disturbance due to badger and fox activity had a positive effect on herbaceous species richness. Interestingly, this effect did not differ between the studied carnivores despite their obvious differences in burrowing intensity.

Plants colonizing ground disturbed by animals have been shown frequently to be very different from those in 

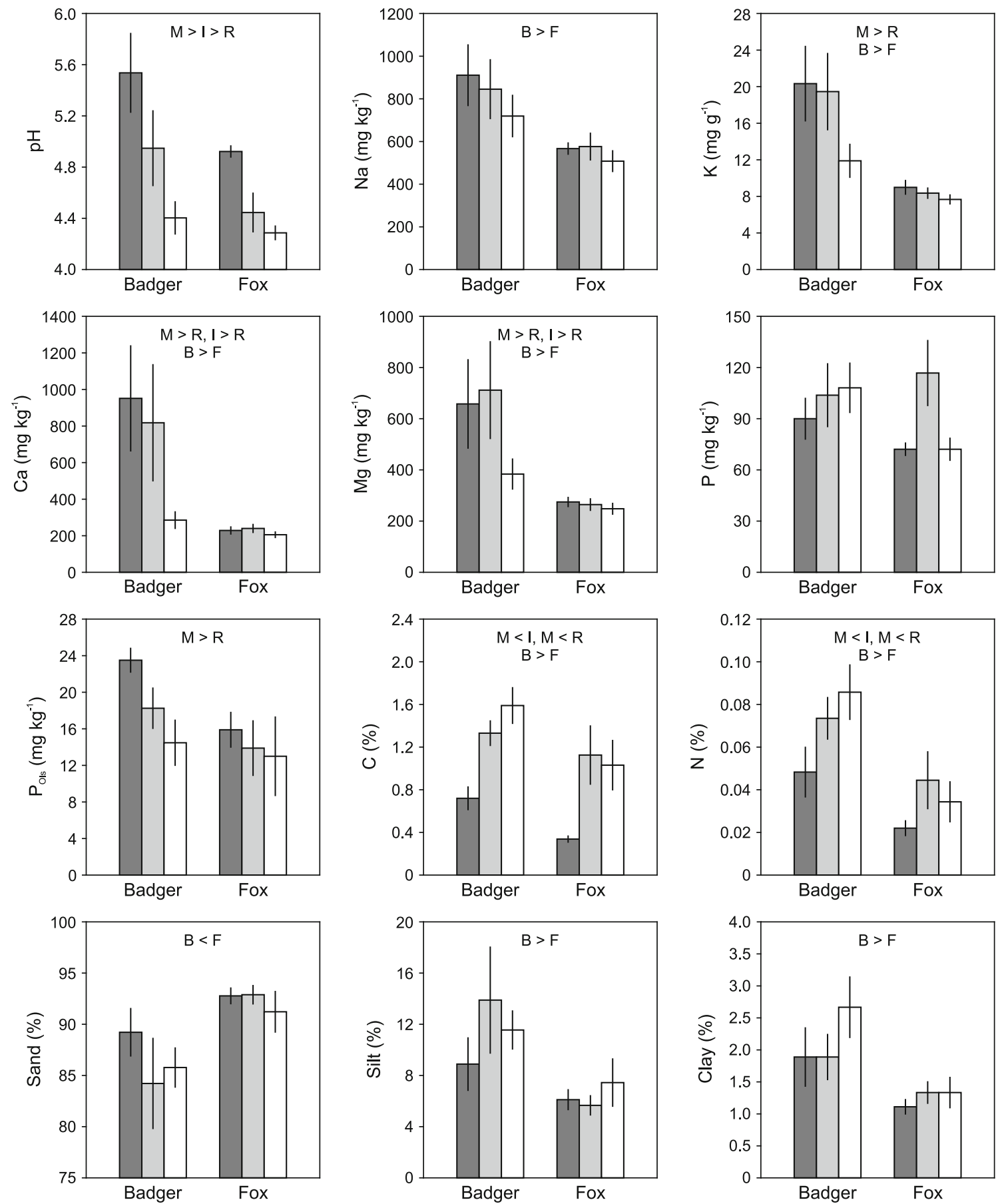

$\square$ Mound area (M) $\square$ Intermound area (I) $\square$ Reference area (R)

Fig. 2 Soil physicochemical properties (means and standard errors) determined for three disturbance levels - mound (M), intermound (I) and reference areas (R) at badger (B) and fox

surrounding areas in terms of plant functional traits. They are referred to as fugitive species (e.g., Platt 1975; Armstrong 1976). The group comprises annuals, biennials and perennials typical for transient environments or early succession stages. Usually they replace longerliving dominant species (e.g., woody plants), which are
(F) sites. Inequality signs indicate significant differences for the disturbance effect (between M, I and R) and for the species site effect (between $\mathrm{B}$ and $\mathrm{F}$ )

unable to regenerate quickly after disturbance. In our study, the fugitive species were represented mostly by hemicryptophytes, among which ruderal forbs (e.g., Urtica dioica, Chelidonium majus, Mycelis muralis, Geum urbanum) prevailed. Ruderals are plants with a short life cycle and high seed output. As a rule, their seeds are 
spread easily by wind or animals and can reach distant habitats various in type. They rarely find opportunities to germinate, however. For example, in the pine and mixed oak-pine forests studied here, ruderals cannot germinate as long as a thick layer of litter and humus covers the mineral soil. Those obstacles vanish wherever animals excavate soil and bury the original forest floor (Mayer et al. 2004; Schnoor and Olsson 2010). Seeds of some species like Urtica dioica and Mycelis muralis are particularly adapted to such disturbance episodes. They form a persistent seed bank and are highly responsive to light - an indicator of disturbances in the environment (Jankowska-Błaszczuk and Grubb 1997; Milberg et al. 2000). This trait enables them to establish quickly after topsoil continuity and the original vegetation layers are broken (light-demanding species seem to be especially favoured by badgers, which can eliminate from their burrows a significant number of Frangula alnus individuals).

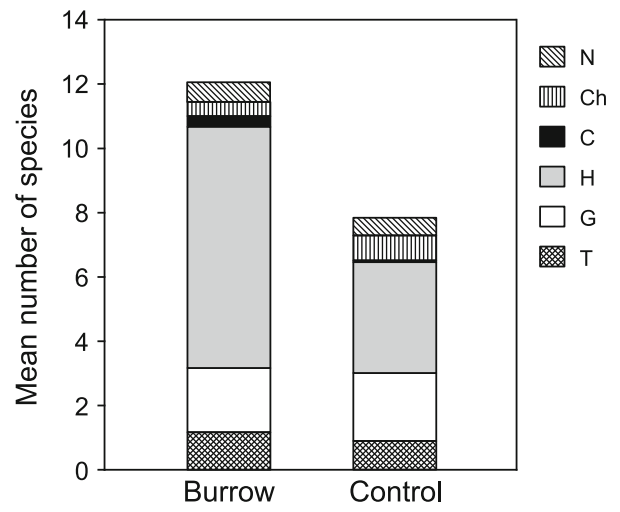

Fig. 3 Average number of species of different life forms occurring in burrow and control plots. $N$ Nanophanerophytes, $C h$ woody chamaephytes, $C$ herbaceous chamaephytes, $H$ hemicryptophytes, $G$ geophytes, $T$ therophytes
Among the plants recorded in the burrow plots, nitrophilous species (e.g., Urtica dioica, Geum urbanum, Chelidonium majus) formed a large group, especially at the badger sites. Similar observations have been reported in other studies (Van Wijngaarden and van de Peppel 1964; Stubbe 1965; Neal and Roper 1991; Neal and Cheeseman 1996; Bruun et al. 2005; Obidziński and Głogowski 2005; Obidziński and Kiełtyk 2006). Most authors speculate that the presence of nitrogendemanding species reflects high nutrient input with animal urine and feces. In other words, fertilization by carnivores, along with soil disturbance, is said to strongly determine plant community composition. We are skeptical of this explanation. First, the authors investigating vegetation on carnivore burrows did not measure the soil nutrient content. They inferred high nutrient input from plant species composition or plant morphology. Such arguments are based on circular reasoning. Our findings suggest that growth conditions (represented by total $\mathrm{N}$ content) may be better outside the burrow plots than inside them. Second, if fertilization by carnivores was a stimulating factor for development of nitrophilous flora, we would observe nitrophilous plants in places where the urine and feces concentration was highest, that is, at the sites of latrines, which are small, shallow holes. We surveyed a great number of badger latrines in the study area and did not record nitrophilous species in them (unpublished data). This indicates that soil disturbances rather than fertilization are the prerequisite for the establishment of these plants. As shown above, such disturbances are accompanied by increased $\mathrm{pH}$ and better supply of some nutrients $(\mathrm{K}, \mathrm{Ca}, \mathrm{Mg}, \mathrm{P})$. Soil disturbance may be the only factor responsible for the appearance of some nutrient-demanding species such as Urtica dioica at burrows.

Badgers and foxes may shape plant communities not only by altering habitat properties but also by facilitating plant propagation. Studies on the animals' diets

Table 3 Plant species present on badger setts (BB), fox dens (FB) and control plots (BC, FC), their frequency over all 36 plots, indicator values, and the significance level $P$ associated with the maximum indicator value

\begin{tabular}{|c|c|c|c|c|c|c|}
\hline \multirow[t]{2}{*}{ Plant species } & \multirow[t]{2}{*}{ Frequency } & \multicolumn{4}{|c|}{ Indicator values } & \multirow[t]{2}{*}{$P$} \\
\hline & & BB & $\mathrm{BC}$ & FB & $\mathrm{FC}$ & \\
\hline \multicolumn{7}{|c|}{ Plant species in the field layer } \\
\hline Chelidonium majus & 8 & $70.7^{*}$ & 0 & 1.0 & 0 & 0.001 \\
\hline Festuca gigantea & 4 & $44.4^{*}$ & 0 & 0 & 0 & 0.013 \\
\hline Geum urbanum & 4 & $44.4^{*}$ & 0 & 0 & 0 & 0.010 \\
\hline Hieracium pilosella & 7 & 1.4 & 1.4 & $41.7^{*}$ & 0 & 0.017 \\
\hline Melampyrum pratense & 10 & 1.1 & 1.1 & 4.4 & $40.0^{*}$ & 0.024 \\
\hline Mycelis muralis & 6 & $34.6^{*}$ & 4.9 & 0 & 0 & 0.032 \\
\hline Peucedanum oreoselinum & 5 & 0 & 0 & $35.6^{*}$ & 2.2 & 0.033 \\
\hline Urtica dioica & 7 & $48.1^{*}$ & 0 & 3.0 & 0 & 0.004 \\
\hline \multicolumn{7}{|c|}{ Shrubs and trees in the understory } \\
\hline Frangula alnus & 30 & 13.6 & $67.3^{*}$ & 7.4 & 5.3 & 0.001 \\
\hline Prunus cerasifera & 10 & $61.1 *$ & 4.2 & 0.3 & 0 & 0.001 \\
\hline Sambucus nigra & 13 & $72.9 *$ & 2.6 & 0.9 & 0.3 & 0.002 \\
\hline
\end{tabular}

* Significant indicator values 
show that badgers and foxes can consume substantial amounts of fruits during summer and autumn (Goszczyński et al. 2000; Sidorovich et al. 2006; Jankowiak et al. 2008; Fedriani and Delibes 2009; Rosalino and Santos-Reis 2009; Kurek 2012), so they are important seed vectors for fleshy-fruited shrubs and trees. Since feces are used to mark territory, a great number of seeds must be spread around burrows.

In this study the diversity of fleshy-fruited shrubs and trees was greater in burrow plots than in control plots, possibly indicating the positive effect of carnivore endozoochory. The distribution of only two plant species was clearly associated with burrows-Sambucus nigra and Prunus cerasifera. Sambucus nigra seeds were rarely found in badger and fox feces in the study area (Kurek 2012), so they probably landed near burrows in bird droppings and established owing to favorable habitat conditions: better soil physicochemical properties and, at the badger sites, reduced competition from a common forest shrub, Frangula alnus. The Prunus cerasifera seeds undoubtedly were dispersed by the carnivores, as they were observed frequently in feces (Kurek 2012). On the other hand, there were no significant differences in the occurrence of Pyrus sp. between the two types of plots even though they were of endozoochorous origin. This may indicate that the animals deposit feces within a large radius of their burrows, reaching the control plots, and that species of the genus Pyrus are capable of establishing in the forest matrix beyond that disturbance zone.

\section{Conclusions}

In this paper we showed that badgers and foxes significantly affect the plant communities around their burrows by disturbing the soil. During sett and den excavation, these carnivores remove the original litter and vegetation of the field and ground layers or bury them under the excavated material. This alters local habitat conditions. Competition from the dominant forest species is reduced and some topsoil chemical properties are modified (increased $\mathrm{pH}$, alkali and alkaline-earth metal content and $\mathrm{P}$ availability). The effect is stronger for the badger, probably because it displaces larger amounts of material and disturbs wider areas. As a result, the area around burrows is colonized by fugitive species, mainly ruderal forbs including nitrophilous species typical of disturbed environments. The animals also affect forest communities in a different way. Being partly frugivorous, badgers and foxes support seed dispersal of some fleshy-fruited shrubs and trees. These plants successfully establish and grow on and around burrows, and together with fugitive species create patches of vegetation different from the forest matrix. Such patches enrich forest biodiversity directly, and may become valuable source of food and microhabitats for other organisms.
Acknowledgments We are grateful to Mr. Jerzy Misiak, Director of Kampinos National Park, for enabling us to conduct the research. The study was supported by the National Science Centre (Poland, Grant No. N N304 307440). The statutory fund of the Institute of Botany of the Polish Academy of Sciences also provided partial funding. Thanks are extended to R. Kowalczyk and second anonymous reviewer for critically reviewing and improving the manuscript.

Open Access This article is distributed under the terms of the Creative Commons Attribution License which permits any use, distribution, and reproduction in any medium, provided the original author(s) and the source are credited.

\section{References}

Andrzejewski R (2003) Kampinoski Park Narodowy [the Kampinos National Park], vol I. A. Grzegorczyk Publishers, Izabelin

Armstrong RA (1976) Fugitive species: experiments with fungi and some theoretical considerations. Ecology 57:953-963

Blaser P, Walthert L, Zimmermann S, Pannatier EG, Luster J (2008) Classification schemes for the acidity, base saturation, and acidification status of forest soils in Switzerland. J Plant Nutr Soil Sci 171:163-170

Boeken B, Shachak M, Gutterman Y, Brand S (1995) Patchiness and disturbance: plant community responses to porcupine diggings in the central Negev. Ecography 18:410-422

Borchard P, McIlroy J, McArthur C (2008) Links between riparian characteristics and the abundance of common wombat (Vombatus ursinus) burrows in an agricultural landscape. Wildl Res 35:760-767

Brady NC, Weil RR (2004) Elements of the nature and properties of soils, 2nd edn. Prentice Hall, Upper Saddle River

Bruun HH, Österdahl S, Moen A, Angerbjörn A (2005) Distinct patterns in alpine vegetation around dens of the Arctic fox. Ecography 28:81-87

Canals R-M, Sebastiá M-T (2000) Soil nutrient fluxes and vegetation changes on molehills. J Veg Sci 11:23-30

Dufrêne M, Legendre P (1997) Species assemblages and indicator species: the for a flexible asymmetrical approach. Ecol Monogr 67:345-366

Eldridge DJ, Koen TB (2008) Formation of nutrient-poor soil patches in a semi-arid woodland by the European rabbit (Oryctolagus cuniculus L.). Austral Ecol 33:88-98

Eldridge DJ, Myers CA (2001) The impact of warrens of the European rabbit Oryctolagus cuniculus on soil and ecological processes in a semi-arid Australian woodland. J Arid Environ 47:325-337

Eldridge DJ, Whitford WG (2009) Badger (Taxidea taxus) disturbances increase soil heterogeneity in a degraded shrub-steppe ecosystem. J Arid Environ 73:66-73

Fedriani JM, Delibes M (2009) Seed dispersal in the Iberian pear, Pyrus bourgaeana: a role for infrequent mutualists. Ecoscience 16:311-321

Fedriani JM, Wiegand T, Delibes M (2010) Spatial pattern of adult trees and the mammal-generated seed rain in the Iberian pear. Ecography 33:545-555

Gálvez-Bravo L, López-Pintor A, Rebollo S, Gómez-Sal A (2011) European rabbit Oryctolagus cuniculus engineering effects promote plant heterogeneity in Mediterranean dehesa pastures. J Arid Environ 75:779-786

Garkaklis MJ, Bradley JS, Wooler RD (2004) Digging and soil turnover by a mycophagous marsupial. J Arid Environ $56: 569-578$

Gołdyn B, Hromada M, Surmacki A, Tryjanowski P (2003) Habitat use and diet of the red fox Vulpes vulpes in an agricultural landscape in Poland. Z Jagdwiss 49:191-200 
Goszczyńska W, Goszczyński J (1977) Effect of the burrowing activities of the common vole and the mole on the soil and vegetation of the biocenoses of cultivated fields. Acta Theriol $22: 181-190$

Goszczyński J (1986) Diet of foxes and martens in central Poland. Acta Theriol 31:491-506

Goszczyński J (1990) Scent marking by red foxes in central Poland during the winter season. Acta Theriol 35:7-16

Goszczyński J, Wójtowicz I (2001) Annual dynamics of den use by red foxes Vulpes vulpes and badgers Meles meles in central Poland. Acta Theriol 46:407-417

Goszczyński J, Jędrzejewska B, Jędrzejewski W (2000) Diet composition of badgers Meles meles in a pristine forest and rural habitats of Poland compared to other European populations. J Zool 250:495-505

Havlin JL, Beaton JD, Tisdale SL, Nelson WL (1999) Soil fertility and fertilizers: an introduction to nutrient management, 6th edn. Prentice Hall, Upper Saddle River

Hobbs RJ, Mooney HA (1985) Community and population dynamics of serpentine grassland annuals in relation to gopher disturbance. Oecologia 67:342-351

Huntly N, Reichman OJ (1994) Effects of subterranean mammalian herbivores on vegetation. J Mammal 75:852-859

Hutchings MR, Service KM, Harris S (2001) Defecation and urination patterns of badgers Meles meles at low density in south west England. Acta Theriol 46:87-96

Jankowiak Ł, Antczak M, Tryjanowski P (2008) Habitat use, food and the importance of poultry in the diet of the red fox $\mathrm{Vul}$ pes vulpes in extensive farmland in Poland. World Appl Sci J 4:886-890

Jankowska-Błaszczuk M, Grubb PJ (1997) Soil seed banks in primary and secondary deciduous forest in Białowieża, Poland. Seed Sci Res 7:281-292

Jęrzejewska B, Jedrzejewski W (1998) Predation in vertebrate communities: the Białowieża Primeval Forest as a case study, 1 st edn. Springer, Berlin

Jobbágy EG, Jackson RB (2001) The distribution of soil nutrients with depth: global patterns and the imprint of plants. Biogeochemistry 53:51-77

Jobbágy EG, Jackson RB (2003) Patterns and mechanisms of soil acidification in the conversion of grasslands to forests. Biogeochemistry 64:205-229

Jones CG, Lawton JH, Shachak M (1994) Organisms as ecosystem engineers. Oikos 69:373-386

Kerley GIH, Whitford WG, Kay FR (2004) Effects of pocket gophers on desert soils and vegetation. J Arid Environ 58:155-166

Kidawa D, Kowalczyk R (2011) The effects of sex, age, season and habitat on diet of the red fox Vulpes vulpes in northeastern Poland. Acta Theriol 56:209-218

Kinlaw A (1999) A review of burrowing by semi-fossorial vertebrates in arid environments. J Arid Environ 41:127-145

Kowalczyk R, Bunevich AN, Jędrzejewska B (2000) Badger density and distribution of setts in Białowieża Primeval Forest (Poland and Belarus) compared to other Eurasian populations. Acta Theriol 45:395-408

Kowalczyk R, Zalewski A, Jędrzejewska B, Jędrzejewski W (2003) Spatial organization and demography of badgers Meles meles in Białowieża Primeval Forest (Poland), and the influence of earthworms on badger densities in Europe. Can J Zool 81:74-87

Kowalczyk R, Zalewski A, Jędrzejewska B (2004) Seasonal and spatial pattern of shelter use by badgers Meles meles in Białowieża Primeval Forest (Poland). Acta Theriol 49:75-92

Kowalczyk R, Jedrzejewska B, Zalewski A, Jedrzejewski W (2008) Facilitative interactions between the Eurasian badger (Meles meles), the red fox (Vulpes vulpes) and the invasive raccoon dog (Nyctereutes procyonoides) in Białowieża Primeval Forest, Poland. Can J Zool 86:1389-1396

Kruuk H (1978) Foraging and spatial organisation of the European badger, Meles meles L. Behav Ecol Sociobiol 4:75-89
Kurek P (2011) Spatial distribution of badger (Meles meles) setts and fox (Vulpes vulpes) dens in relation to human impact and environmental availability. Acta Zool Lit 21:17-23

Kurek P (2012) Depozycja nasion a rozmieszczenie endozoochorycznych drzew i krzewów rozprzestrzenianych przez ssaki drapieżne [Seed shadow and distribution of fleshy fruited shrubs and trees dispersed by carnivores]. PhD thesis. W. Szafer Institute of Botany, Polish Academy of Sciences, Cracow

Kyle GP, Beard KH, Kulmatiski A (2007) Reduced soil compaction enhances establishment of non-native plant species. Plant Ecol 193:223-232

Mayer P, Abs C, Fischer A (2004) Colonisation by vascular plants after soil disturbance in the Bavarian Forest - key factors and relevance for forest dynamics. For Ecol Manag 188:279-289

Milberg P, Andersson L, Thompson K (2000) Large-seeded species are less dependent on light for germination than small-seeded ones. Seed Sci Res 10:99-104

Mirek Z, Piękoś-Mirkowa H, Zając A, Zając M (2002) Flowering plants and pteridophytes of Poland. A checklist. W. Szafer Institute of Botany, Polish Academy of Sciences, Cracow

Neal E, Cheeseman C (1996) Badgers. Poyser, London

Neal E, Roper TJ (1991) The environmental impact of badgers Meles meles and their setts. Symp Zool Soc Lond 63:89-106

Neupane G, Roberts SJ (2009) Quantitative comparison of heavy metals and as accumulation in agricultural and forest soils near Bowling Green, Ohio. Water Air Soil Pollut 197:289-301

Obidziński A, Głogowski R (2005) Changes of forest flora composition in vicinity of dens of red fox and setts of Eurasian badger. Pol J Ecol 53:197-213

Obidziński A, Kiełtyk P (2006) Changes in ground vegetation around badger setts and fox dens in the Białowieża Primaeval Forest, Poland. Pol Bot Stud 22:407-416

Obidziński A, Pabjanek P, Męrzycki P (2013) Determinants of badger Meles meles sett location in Białowieża Primeval Forest, northeastern Poland. Wildl Biol 19:48-68

Panek M, Bresiński W (2002) Red fox Vulpes vulpes density and habitat use in a rural area of western Poland in the end of 1990s, compared with the turn of 1970s. Acta Theriol 47:433-442

Platt WJ (1975) The colonization and formation of equilibrium plant species associations on badger disturbances in a tall-grass prairie. Ecol Monogr 45:285-305

Questad EJ, Foster BL (2007) Vole disturbances and plant diversity in a grassland metacommunity. Oecologia 153:341-351

Roberts DW (2012) Package "labdsv": ordination and multivariate analysis for ecology. R package version 1.5-0. http://ecology. msu.montana.edu/labdsv/R

Rosalino LM, Santos-Reis M (2009) Fruit consumption by carnivores in Mediterranean Europe. Mamm Rev 39:67-78

Rost J, Pons P, Bas JM (2012) Seed dispersal by carnivorous mammals into burnt forests: an opportunity for non-indigenous and cultivated plant species. Basic Appl Ecol 13:623-630

Schnoor TK, Olsson PA (2010) Effects of soil disturbance on plant diversity on calcareous grasslands. Agric Ecosyst Environ 139:714-719

Sidorovich VE, Sidorovich AA, Izotova IV (2006) Variations in the diet and population density of the red fox Vulpes vulpes in the mixed woodlands of northern Belarus. Mamm Biol 71:74-89

Stubbe M (1965) Zur Biologie der Raubtiere eines abgeschlossenen Waldgebietes. Z Jagdwiss 11:73-102

R Development Core Team (2009) R: a language and environment for statistical computing. R Foundation for Statistical Computing, Vienna. http://www.r-project.org

Uraguchi K, Takahashi K (1998) Den site selection and utilization by the red fox in Hokkaido, Japan. Mamm Stud 23:31-40

Van Wijngaarden A, van de Peppel J (1964) The Badger, Meles meles (L.), in the Netherlands. Lutra 6:1-60

Veen GF, Olff H (2011) Interactive effects of soil-dwelling ants, ant mounds and simulated grazing on local plant community composition. Basic Appl Ecol 12:703-712 
Wesche K, Nadrowski K, Retzer V (2007) Habitat engineering under dry conditions: the impact of pikas (Ochotona pallasi) on vegetation and site conditions in southern Mongolian steppes. J Veg Sci 18:665-674

Whitford WG, Steinberger Y (2010) Pack rats (Neotoma spp.): keystone ecological engineers? J Arid Environ 74:1450-1455
Wilkinson MT, Richards PJ, Humphreys GS (2009) Breaking ground: pedological, geological, and ecological implications of soil bioturbation. Earth-Sci Rev 97:257-272

Wilson SD, Tilman D (1993) Plant competition and resource availability in response to disturbance and fertilization. Ecology 74:599-611 